\title{
Fathers and Forefathers: Men and Their Children in Genealogical Perspective
}

\author{
Martin Robb \\ Faculty of Wellbeing, Education and Language Studies, The Open University, Milton Keynes MK7 6AA, UK; \\ martin.robb@open.ac.uk
}

Received: 9 June 2020; Accepted: 17 June 2020; Published: 19 June 2020

\begin{abstract}
This editorial article introduces the seven contributions to the special issue "Fathers and Forefathers: Men and their Children in Genealogical Perspective". It highlights the geographical, historical and methodological diversity of the contributions, as well as their commonalities, and the different ways in which they use a genealogical perspective to explore the relationship between past and present fatherhoods. The special issue, as a whole, aims to deepen the understanding of this relationship and to point the way for future theoretical and empirical work on this important topic.
\end{abstract}

Keywords: fathers; fatherhood; masculinities; history

Research on fathers and fatherhood has blossomed in the past two decades, with a number of ground-breaking studies appearing, for the most part illuminating present-day fathering experiences (e.g., Doucet 2006; Dermott 2008 and Miller 2011), but also beginning to uncover hidden narratives of past fatherhoods (e.g., Tosh 2007 and King 2015). This special issue aims to add something new to this expanding field by exploring the dynamic relationship between present and past fatherhoods.

Popular understandings of fathers in past generations, as being detached and uninvolved in the lives of their children, can be said to play a significant part in the construction of modern fathering identities, with many men defining themselves in opposition to the way they recall being fathered, and ideas of "new" fatherhood being played off against mythicized notions of historical fathering practices (see Robb 2020a). However, historical research has begun to show that these popular myths often misremember the past, judging it by current standards, and obscure the diverse nature of fathering practices in the recent and historical past, as well as globally and interculturally.

A genealogical approach to the study of fathers and fatherhood can critically examine these intergenerational constructions of fatherhood, and more positively illuminate the ways in which experiences of fathering and being fathered are passed on between generations. As Philip Kretsedemas wrote in the editorial to the inaugural issue of this journal, "genealogies can operate as a method for tracing pathways that unravel the definitions we impose on things and for exposing the limitations of familiar narratives" (Kretsedemas 2017).

For this special issue, we invited contributions that used a genealogical approach (broadly defined) to fathering and fatherhood, as a way of defamiliarizing accepted narratives and suggesting new ways of thinking about men and their relationships with their children.

The seven papers published as part of this special issue represent a rich and diverse range of responses to this invitation. The papers are diverse in their geographical coverage, written by researchers based in England, Scotland, Italy and Canada, and representing research from three continents. They are also richly diverse in their interpretation of the genealogical focus of the invitation, and indeed of the journal. Three of the papers (those by Ruxton, Scholar and Robb) draw on their authors' own genealogical research into their families' histories, demonstrating some of the ways in which these personal micro-histories can be a fertile resource for understanding fathering in the past, 
and the interaction between past and present fatherhoods. Scholar's (Scholar 2020) article explores the ways in which DNA testing can "disrupt and unsettle" accepted family histories and notions of paternity, while Ruxton's (Ruxton 2020) and Robb's (Robb 2020b) examinations of memoirs and letters written by fathers in the time of war both illuminate and challenge stereotypical understandings of fatherhood in the past, as well as contributing to deepening the understanding of the often unexplored affective dimensions of fatherhood, and indeed of masculinity.

Three other papers are more broadly historical, with Grant and Bowe's article (Grant and Bowe 2020) exploring how stereotypical understandings of African-American fatherhood in the past continue to shape negative perceptions of black families in the present. Writing from Italy, Bosoni and Mazzucchelli (2019) use a review of the academic literature on fatherhood, published in two time periods in the recent past, to explore both generational differences and current debates about the supposedly changing nature of fatherhood. Clapton's paper (Clapton 2019) focuses on the history of a particular form of fatherhood, that of a child given up for adoption, in the process problematizing the concept of the "birth father", and prompting a re-evaluation of the ways in which the identity of "father" is conceptualized. The article resonates with recent debates about "absent" fathers, and with recent work, including some undertaken by the present author, on the consequences of losing a child in the perinatal period for fathering identities (Jones et al. 2019).

The contribution to the special issue by eminent fatherhood scholar Doucet (2019) is more explicitly theoretical in its approach than the others, setting out to provide a "Foucauldian-inspired genealogy" of a key concept in fatherhood studies: the notion of "father involvement". In so doing, Doucet seeks to disrupt the binary opposition between breadwinning and caregiving in academic and policy discussions of fatherhood. Like the more empirical contributions to this issue, this article prompts the reader to look at fatherhoods past and present, and the relationship between the two, with fresh eyes. It is to be hoped that this piece, like the special issue as a whole, will inspire new directions and developments, both theoretical and empirical, in this important and developing field of research.

Funding: This research received no external funding.

Conflicts of Interest: The author declares no conflict of interest.

\section{References}

Bosoni, Maria Letizia, and Sara Mazzucchelli. 2019. Generations Comparison: Father Role Representations in the 1980s and the New Millennium. Genealogy 3: 17. [CrossRef]

Clapton, Gary. 2019. Against All Odds? Birth Fathers and Enduring Thoughts of the Child Lost to Adoption. Genealogy 3: 13. [CrossRef]

Dermott, Esther. 2008. Intimate Fatherhood: A Sociological Analysis. London and New York: Routledge.

Doucet, Andrea. 2006. Do Men Mother? Fathering, Care and Domestic Responsibility. Toronto: University of Toronto Press.

Doucet, Andrea. 2019. Father Involvement, Care, and Breadwinning: Genealogies of Concepts and Revisioned Conceptual Narratives. Genealogy 4: 14. [CrossRef]

Grant, Susan-Mary, and David Bowe. 2020. “My Daddy ... He Was a Good Man”: Gendered Genealogies and Memories of Enslaved Fatherhood in America's Antebellum South. Genealogy 4: 43. [CrossRef]

Jones, Kerry, Martin Robb, Sam Murphy, and Alison Davies. 2019. New understandings of fathers' experiences of grief and loss following stillbirth and neonatal death: A scoping review. Journal of Midwifery 79: 102531. [CrossRef] [PubMed]

King, Laura. 2015. Family Men: Fatherhood and Masculinity in Britain, 1914-1960. Oxford: Oxford University Press. Kretsedemas, Philip. 2017. What Is Genealogy? Introduction to the Inaugural Issue of Genealogy. Genealogy 1: 10. [CrossRef]

Miller, Tina. 2011. Making Sense of Fatherhood: Gender, Caring and Work. Cambridge: Cambridge University Press. Robb, Martin. 2020a. Men, Masculinities and the Care of Children: Images, Ideas and Identities. London and New York: Routledge. 
Robb, Martin. 2020b. "From Your Ever Anxious and Loving Father": Faith, Fatherhood, and Masculinity in One Man's Letters to His Son during the First World War. Genealogy 4: 32. [CrossRef]

Ruxton, Sandy. 2020. Masculinity, Intimacy, and Mourning: A Father's Memoir of His Son Killed in Action in World War II. Genealogy 4: 59. [CrossRef]

Scholar, Helen. 2020. The Ghost of the 'Y': Paternal DNA, Haunting and Genealogy. Genealogy 4: 3. [CrossRef] Tosh, John. 2007. A Man's Place: Masculinity and the Middle-Class Home in Victorian England. New Haven: Yale University Press.

(c)

(C) 2020 by the author. Licensee MDPI, Basel, Switzerland. This article is an open access article distributed under the terms and conditions of the Creative Commons Attribution (CC BY) license (http://creativecommons.org/licenses/by/4.0/). 